\title{
Serum Level of Uromodulin as an Early Predictor Marker of Kidney Disorders
}

\author{
Salwa Mostafa El Shebini ${ }^{1 *}$, Hend A. Essa ${ }^{1}$, Maha I. A. Moaty ${ }^{1}$, Nihad H. Ahmed ${ }^{1}$, Ahmed M. S. Hussein ${ }^{2}$, \\ Magda S. Mohamed ${ }^{1}$, Salwa T. Tapozada ${ }^{1}$ \\ ${ }^{1}$ Department of Nutrition and Food Science, National Research Center, Cairo, Egypt; ${ }^{2}$ Department of Food Technology, National \\ Research Center, Cairo, Egypt
}

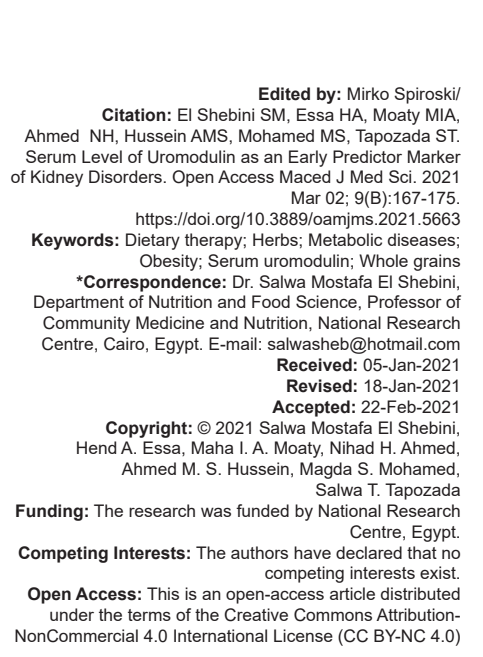

\begin{abstract}
BACKGROUND: Metabolic diseases are known to be risk factors of kidney injury. The glycoprotein Uromodulin Tamm-Horsfall protein is a biochemical marker specifically synthesized and secreted by kidney tubular epithelial cells.

AIM: The study aimed to use novel biochemical parameters to predict early changes in renal functions and to use natural food supplements to help in the prevention and management of such conditions.

METHODS: Crossover studies comparing two interventions trials. Subjects: Seventy obese females were included in this study. They were divided in two groups, first group (34 women) with mean age $45.82 \pm 1.51$ and mean body mass index (BMI) $35.65 \pm 0.68 \mathrm{~kg} / \mathrm{m}^{2}$, and second group (36 women) with mean age $49.80 \pm 2.27$, and mean BM $37.67 \pm 1.59$. Intervention: All participants have followed a low caloric balanced regimen (1000-1200 Kcal/day) of the each groups consumed a different specific nutritional supplement composed mainly of whole grains and herbs. All patients were monitored clinically, anthropometrically, dietary $24 \mathrm{~h}$ recall and biochemically.

RESULTS: After intervention all the recorded anthropometric parameters showed significant decreases at $p \leq 0.05$ 0.01 . The serum uromodulin (sUMOD) increased significantly after intervention in both groups the increments were 15.56 and $9.37 \%$. Numerically creatinine and urea decreased, while creatinine clearance increased.

CONCLUSION: Data revealed the importance of using dietary therapy composed of hypocaloric diet with supplements made from whole grains and special herbs in management of obesity and its metabolic disorders. sUMOD proved to be an accurate biochemical marker that showed the kidneys' response to the management in comparison to using usual diagnostic markers.
\end{abstract}

\section{Introduction}

Obesity, diabetes, and hypertension are the most important metabolic diseases known to be hazardous factors of kidney disease, and playing a vital part within the progression of chronic kidney disease (CKD) [1], [2], [3]. In the developed countries, hypertension and diabetes have been the leading causes of CKD.

In the United States, $40 \%$ of diabetic patients suffered from some degree of CKD [4], while in Japan $40-50 \%$ of diabetic patients suffered from kidney damage [5]. In the meantime in Turkey, around $25.3 \%$ of patients with hypertension were exposed to kidney injury [6]. High susceptibility of overweight and obese subjects to CKD was reported in Norway with a relative risk of 1.77 [7]. The most elevated prevalence of type 2 diabetes mellitus reported in the Arab countries is found in the Kingdom of Saudi Arabia (31.6\%), Oman (29\%), Kuwait $(25.4 \%)$, the United Arab Emirates (25.0\%), Bahrain (25.0\%), Mauritania (4.7\%), and Somalia $(3.9 \%)$ have the least prevalence.
Worldwide, CKD patients who might need renal replacement therapy increased greatly. In USA and Japan, the number of patients with end stage renal disease (ESRD) has increased by about $9 \%$ and $4 \%$ every year, respectively [8], [9]. Prevalence of dialysis patients in Egypt is found to increase, and the fundamental cause of ESRD, other than diabetic nephropathy, is hypertensive kidney sickness, chronic pyelonephritis and glomerulonephritis, obscure etiology, schistosomal obstructive uropathy, and nephropathy [10], [11].

Obesity and the metabolic disorders are hazardous factors for CKD. Alterations of kidney functions be that as it may, early kidney adjustments may get away from determination in these conditions because of glomerular hyperfiltration. Uromodulin Tamm-Horsfall protein, a glycoprotein only blended in cylindrical cells of the thick rising appendage of Henle's circle, is a novel tissue-explicit biomarker for kidney work. As opposed to the normally utilized markers creatinine and cystatin C, sUMOD does not fundamentally rely upon glomerular filtration [12]. sUMOD is a novel delicate kidney-explicit biomarker 
connected to the auxiliary respectability of the distal nephron and to renal capacity [13].

Numerous dietary interventions have been proposed to improve the outcomes of the ongoing chronic diseases [14], [15], [16]. Corn, not withstanding being the primary staple food in numerous nations, is utilized in the production of many products. Corn contains components that have a great benefit for health, for example, phenolic compounds, carotenoids, vitamin $\mathrm{E}$, and minerals that go about as cofactors for antioxidant enzymes [17]. Barley grass might be a standout among other practical foods for the management of chronic diseases, and the best crude material use in the design of modern foods that help in building enormous healthy food industry. Furthermore, research has shown that barley contains Gamma-Aminobutyric acid, flavonoids, potassium, calcium, and tryptophan. All of these are nutritional bioactive compounds proved to play an important role in the protection and treatment of many chronic diseases [18]. Culinary spices are herbaceous (leafy) plants that add color and flavor to a wide range of meals. Around the worldwide, there is a wide assortment of spices that are utilized for culinary purposes, which are additionally perceived for their helpful healthy impacts and accordingly have likewise been utilized in folk medicine. Other than their dietary benefit spices are rich in numerous phytochemical with bioactive impacts, in this manner improving human health [19].

The aim of this study was to demonstrate the effect of obesity and the metabolic chronic diseases on the kidney functions in obese patients. The study aimed to use novel biochemical parameters to predict early changes in renal functions and to define better tools for diagnoses and follow-up. In addition, to the use dietary therapy using natural food supplements aiming to help in prevention and management of such complications was targeted.

\section{Subjects and Methods}

\section{Methods}

The corn pie supplement was prepared from corn flour, wheat flour (72\% extraction), and wheat germ added in a ratio $40 \%, 30 \%$, and $5 \%$, respectively. The mixture was mixed with the other ingredients (skimmed milk, corn oil, thyme, and yeast) and kneaded with suitable amount of water. The dough was left to ferment for enough time, and then formed as pies that were baked at $180^{\circ} \mathrm{C}$ for about $15 \mathrm{~min}$ [20]. Barley Talbina supplement was made by mixing barley flour with cocoa powder, ginger powder, and arabic gum in a ratio $70.9 \%, 7 \%, 2 \%$, and $0.1 \%$. The blend was cooked with water for $10 \mathrm{~min}$, left to cool, and then an appropriate amount of milk (contained $20 \%$ dry milk) was added to obtain a suitable thickness (Table 1).
Table 1: Composition of the corn pie and Barley Talbina (g/100 g dry weight)

\begin{tabular}{lll}
\hline Ingredients & Corn pie & Barley Talbina \\
\cline { 2 - 3 } & Percent & Percent \\
\hline Corn flour & 40.0 & - \\
Wheat flour $(72 \%)$ & 30.0 & - \\
Wheat germ & 5.0 & - \\
Dry milk & 10.0 & 20.0 \\
Corn oil & 10.0 & - \\
Thyme & 3.0 & - \\
Yeast & 2.0 & - \\
Barley flour & - & 70.9 \\
Cocoa powder & - & 7.0 \\
Ginger powder & - & 2.0 \\
Arabic gum & - & 0.10 \\
\hline
\end{tabular}

\section{Chemical analysis}

Moisture, ash, fiber, protein, and fat of the supplements were determined according to AOAC [20]. Individual elements ( $\mathrm{Fe}, \mathrm{K}, \mathrm{Na}, \mathrm{Ca}, \mathrm{Mg}$, and $\mathrm{Zn}$ ) in all samples were determined according to the method described by Kazuyoshi and Yuuko [21]. Fatty acids analysis was determined by using gas chromatography-mass spectrometer detector method validation based on berry seed extract samples, and polyphenols were determined using standard methods [22], [23].

\section{Subjects}

\section{Study design}

Seventy obese females with body mass index $(\mathrm{BMI}) \geq 30$ were included in this study, after applying the exclusion criteria: Participants who were taking any medication or multivitamin supplements or suffering from chronic diseases, allergic conditions, co-infection, smoking, or other major illnesses. They were divided in two groups, first group (34 women) with mean age $45.82 \pm 1.51$ and mean BMI $35.65 \pm$ $0.68 \mathrm{~kg} / \mathrm{m}^{2}$, and second group (36 women) with mean age $49.80 \pm 2.27$ and mean BMl $37.67 \pm 1.59 \mathrm{~kg} / \mathrm{m}^{2}$. They were all enrolled in a program for losing weight in the Nutrition Department, National Research Centre. The participants were informed about the purpose of the study and their permission in the form of written consent was obtained. The research was given ethical approval from the Ethical Committee of the National Research Centre (Registration Number 19-180). All participants have followed a low caloric balanced regimen (1000-1200 Calorie/day) for 8 weeks. The first group consumed the corn pie, one pie with breakfast and one with dinner (each weighed $20 \mathrm{~g}$ ), the second group consumed Barley Talbina $30 \mathrm{~g}$ of the dry weight at breakfast and $15 \mathrm{~g}$ at dinner. All the subjects were examined at baseline, and the end of the study with weekly follow-up.

The study was conducted in the period from the beginning of November to the end of December 2019 . 


\section{Anthropometric parameters and blood pressure measurements}

Relevant anthropometric measurements were reported including height and weight using standardized equipment and following the recommendations of the International Biological Program [24]. BMI and waist hip ratio (WHR) were calculated (weight in $\mathrm{kg} / \mathrm{height}^{2}$ in meter, waist/hip ratio in $\mathrm{cm}$ ). Body fat (BF) as a percent of body weight was measured using Geratherm Body Fitness (B-5010), German. Blood pressure for each patient was measured 3 times and the mean was recorded.

\section{Dietary history}

Data on dietary intake before the intervention were reported using the $24 \mathrm{~h}$ dietary intake recall. All food items and portions were recorded in details. Total nutrients intake was calculated before and after intervention using Nutrisurvey 2007.

\section{Blood samples and biochemical analysis}

Blood samples were obtained on the day of clinical examination after an overnight fast. The blood samples were allowed to clot, centrifuged and sera separated and divided into aliquots and stored in Eppendorf tubes at $-70^{\circ} \mathrm{C}$ until used for further analysis.

Serum total cholesterol (TC) and high-density lipoprotein cholesterol (HDL-C) were done using; cholesterol proceed No 1010, StanBioLiquicolor [25]. HDL-C proceeds No 0599 StanBioLiquicolor [26]. NonHDL-C was calculated TC-HDL-C, while risk factor calculated as TC/HDL-C. Creatinine was estimated by kinetic methods using the kit supplied by Erba Lachema s.r.o., Karásek 1d, 62100 Brno, CZ. REF/ BLT00020 [27]. Creatinine Clearance was calculated according to the Cockcroft-Gault Equation [28]: [[140 -age(yr)] ${ }^{*}$ weight(kg)]/[72* serum $\left.\mathrm{Cr}(\mathrm{mg} / \mathrm{dL})\right]$ (multiply by 0.85 for women). Urea was estimated by colorimetric method [29]. Uromodulin was estimated by ELISA Kit, supplied by EIAab® Catalog No: E2280h [30].

\section{Statistical analysis}

The study compared two interventional trials in which two groups of obese women consumed two different supplements. The reported data were compared within each group before and after the dietary intervention. All values were expressed as mean value \pm SE. Two-tailed student t-test was used to compare between data in the same group. Changes in different data were expressed as \% change from baseline. Correlation coefficient ( $r$ ) was calculated to find correlations between different variables. $p<0.05$ were considered statistically significant. Statistical analysis was performed using SPSS (10) software. SPSS window software version 17.0 (SPSS Inc. Chicago, IL, USA, 2008) was used.

\section{Results}

Table 2 shows the chemical analysis of the two supplements. The moisture content of the corn pie and Barley Talbina samples was 5.16 and 8.69, respectively. On the other hand, the protein, fat, and fiber contents were higher in pie $(18.42,13.0$, and $2.81 \%)$ compared to barley Talbina $(15.79,7.09$, and $2.21 \%)$, respectively. The total carbohydrates and ash contents were higher in the Talbina compared to the corn pie. Total phenols of pie were higher than those of Talbina.

Table 2: Chemical composition of corn pie and Barley Talbina ( $\mathrm{g} / 100 \mathrm{~g}$ of dry weight basis)

\begin{tabular}{llllllll}
\hline Samples & Moisture & Protein & Fat & Ash & Fiber & Carbohydrates & $\begin{array}{l}\text { Total phenols } \\
\text { (mg GAE/g) }\end{array}$ \\
\hline $\begin{array}{l}\text { Corn pie } \\
\begin{array}{l}\text { Barley } \\
\text { Talbina }\end{array}\end{array}$ & 5.16 & 18.42 & 13.0 & 1.82 & 2.81 & 63.95 & 1.08 \\
\hline & 15.79 & 7.09 & 2.04 & 2.21 & 72.87 & 0.90 \\
\hline
\end{tabular}

Table 3 shows the levels of minerals $(\mathrm{mg} / 100 \mathrm{~g})$ in the tested samples. Data revealed that the corn pie and Talbina contain an adequate amount of minerals. The results also show that the corn pie contained a greater amount of iron and potassium, while the Talbina contained more sodium, calcium, and zinc.

Table :3 Levels of minerals $(\mathrm{mg} / 100 \mathrm{~g}$ ) in the tested samples

\begin{tabular}{lllllll}
\hline Samples & $\mathrm{Fe}$ & $\mathrm{K}$ & $\mathrm{Na}$ & $\mathrm{Ca}$ & $\mathrm{Mg}$ & $\mathrm{Zn}$ \\
\hline Corn flour & 32.83 & 132.36 & 35.10 & 345.87 & 530.88 & 15.31 \\
Wheat flour $(72 \%)$ & 60.32 & 195.77 & 16.21 & 120.59 & 478.91 & 11.65 \\
Wheat germ & 93.84 & 101.61 & 130.35 & 243.30 & 56.40 & 17.58 \\
Thyme & 88.53 & 118.50 & 568.28 & 967.57 & 27.52 & 26.10 \\
Corn pie & 65.63 & 455.96 & 88.44 & 213.63 & 119.20 & 27.25 \\
Barley flour & 40.93 & 251.32 & 33.30 & 138.58 & 623.70 & 17.56 \\
Cocoa powder & 102.42 & 449.35 & 40.48 & 466.77 & 495.46 & 88.34 \\
Ginger & 67.87 & 944.61 & 294.55 & 114.90 & 161.72 & 99.26 \\
Arabic gum & 26.47 & 247.74 & 32.42 & 125.71 & 125.03 & 7.35 \\
Barley Talbina & 40.88 & 193.67 & 134.95 & 683.10 & 495.43 & 120.92 \\
\hline
\end{tabular}

Table 4 showed the calories delivered from fat, protein, and carbohydrates of the habitual diet and the two different types of regimens. The total daily calories consumed by the participants followed the two types of the regimens significantly decreased when compared to the habitual diet. The percent of the calories obtained from the saturated fatty acids of the two regimens significantly decreased, while the

Table 4: Calories delivered from fat, protein, and carbohydrates of the habitual diet and the three different types of regimens consumed by the obese volunteers

\begin{tabular}{|c|c|c|c|c|}
\hline Items & Habitual diet & $\begin{array}{l}\text { Regimen with } \\
\text { corn pie }\end{array}$ & $\begin{array}{l}\text { Regimen with } \\
\text { Barley Talbina }\end{array}$ & p-value \\
\hline Total calories & $2459.33 \pm 33.92$ & $1038.28 \pm 23.10$ & $1035.47 \pm 20.48$ & $0.000^{\star \star}$ \\
\hline Fat $(25-35 \%)$ & 40.27 & 41.24 & 38.82 & 0.058 \\
\hline $\begin{array}{l}\text { SFA (No more } \\
\text { than } 7 \% \text { ) }\end{array}$ & 24.16 & 6.99 & 6.96 & $0.000^{\star \star}$ \\
\hline $\begin{array}{l}\text { MUFA } \\
(12-14 \%)\end{array}$ & 6.59 & 14.38 & 14.74 & $0.011^{*}$ \\
\hline $\begin{array}{l}\text { PUFA } \\
(6-8 \%)\end{array}$ & 5.49 & 8.38 & 8.47 & $0.030^{*}$ \\
\hline $\begin{array}{l}\text { Protein } \\
(10-30 \%)\end{array}$ & 6.73 & 19.31 & 18.92 & $0.014^{\star}$ \\
\hline $\begin{array}{l}\text { Carbohydrates } \\
(45-65 \%)\end{array}$ & 52.99 & 39.45 & 42.26 & $0.020^{*}$ \\
\hline
\end{tabular}


percent of the mono-unsaturated fatty acids (MUSFAs) and poly-unsaturated fatty acids (PUFAs) significantly increased, all reached the recommended levels after the intervention. Significant increase reported in the percent of the calories derived from the daily protein intake, and significant decrease in the percent of calories derived from the carbohydrate.

Table 5 showed the characteristic anthropometric parameters, blood pressure, and biochemical parameters of the studied obese women before and after dietary therapy. After intervention all the recorded anthropometric parameters showed significant decreases at $p \leq 0.05-0.01$. The mean BMI reported for the participants in both groups was $35.65 \pm 0.68$ and $37.67 \pm 1.59$ which indicated grade II obesity. Systolic blood pressure and diastolic blood pressure (DBP) decreased in both groups after intervention. Significant differences of both values found in the group who consumed the barley Talbina, while participants consumed pie showed significant difference only with the DBP. Significant percent decrease in the serum non-HDL-C concentration and the calculated risk factor was -13.82 and $-12.95 \%$ and -21.50 and 29.76 for both groups, respectively. Biochemical parameters concerning kidney functions, namely creatinine and urea decreased numerically while creatinine clearance numerically increases. The sUMOD increased significantly after intervention in both groups the increments were 15.56 and $9.37 \%$ for the pie and the Barley Talbina, respectively. The mean creatinine/sUMOD ratio showed significant difference among the group consumed Barley Talbina.

Table 6 shows correlation coefficient of sUMOD and some anthropometric and biochemical parameters.

Table 5: Some anthropometric parameters and blood pressure of the studied obese women before and after dietary therapy

\begin{tabular}{|c|c|c|c|c|c|c|}
\hline \multirow[t]{3}{*}{ Parameters } & \multicolumn{2}{|c|}{$1^{\text {st }}$ Group (Consuming corn pie) $(\mathrm{n}=34)$} & \multirow[t]{3}{*}{$\%$ Change } & \multicolumn{2}{|c|}{$2^{\text {nd }}$ Group (Consuming Barley Talbina) $(n=36)$} & \multirow[t]{3}{*}{$\%$ Change } \\
\hline & Before intervention & After intervention & & Before intervention & After intervention & \\
\hline & Mean \pm SE & & & Mean \pm SE & & \\
\hline Age (year) & $45.82 \pm 1.51$ & & & $49.80 \pm 2.27$ & & \\
\hline Height $(\mathrm{cm})$ & $157.32 \pm 0.94$ & & & $154.87 \pm 0.88$ & & \\
\hline $\mathrm{BMI}\left(\mathrm{kg} / \mathrm{m}^{2}\right)$ & $35.65 \pm 0.68$ & $34.59 \pm 0.98^{\star *}$ & -2.97 & $37.67 \pm 1.59$ & $35.72 \pm 1.34^{* *}$ & -5.18 \\
\hline $\mathrm{BF}(\%)$ & $47.33 \pm 0.63$ & $46.44 \pm 0.68^{\star}$ & -1.88 & $49.40 \pm 0.97$ & $48.28 \pm 0.95^{\star *}$ & -2.27 \\
\hline Body muscle $(\mathrm{kg})$ & $43.04 \pm 0.63$ & $42.66 \pm 0.63^{*}$ & -0.88 & $43.07 \pm 0.89$ & $42.53 \pm 0.75^{\star}$ & -1.25 \\
\hline BMR (kcal) & $2127.58 \pm 36.13$ & $2071.89 \pm 32.64^{\star *}$ & -2.61 & $2157.50 \pm 37.50$ & $2082 \pm 39.52^{*}$ & -3.50 \\
\hline Chest $(\mathrm{cm})$ & $97.68 \pm 1.07$ & $94.34 \pm 0.81^{* *}$ & -3.41 & $96.70 \pm 1.94$ & $92.45 \pm 1.90^{\star *}$ & -4.40 \\
\hline Abdominal $2(\mathrm{~cm})$ & $113.00 \pm 1.54$ & $109.95 \pm 95^{\star *}$ & -2.69 & $117.95 \pm 2.38$ & $114.70 \pm 2.42^{\star \star}$ & -2.76 \\
\hline WHR $(\mathrm{cm} / \mathrm{cm})$ & $0.77 \pm 0.01$ & $0.76 \pm 0.01^{* *}$ & -1.29 & $0.77 \pm 0.01$ & $0.75 \pm 0.01^{* *}$ & -2.60 \\
\hline $\operatorname{Neck}(\mathrm{cm})$ & $34.03 \pm 0.28$ & $31.95 \pm 1.14$ & -6.11 & $33.60 \pm 0.64$ & $33.20 \pm 0.51^{*}$ & -1.19 \\
\hline $\mathrm{SBP}(\mathrm{mmHg})$ & $121.84 \pm 2.17$ & $120.26 \pm 1.89$ & -1.29 & $119.50 \pm 3.18$ & $115.50 \pm 2.83^{*}$ & -3.35 \\
\hline $\mathrm{DBP}(\mathrm{mmHg})$ & $81.32 \pm 1.30$ & $78.16 \pm 1.26^{\star \star}$ & -3.88 & $80.50 \pm 1.81$ & $77.50 \pm 1.72^{\star}$ & -3.73 \\
\hline Non-HDL-C (mg/dl) & $172.94 \pm 6.84$ & $149.05 \pm 6.15^{\star *}$ & -13.82 & $199.77 \pm 7.01$ & $173.90 \pm 4.69^{* *}$ & -12.95 \\
\hline Risk factor (TC/HDL-C) & $6.51 \pm 0.23$ & $5.11 \pm 0.20^{* \star}$ & -21.50 & $7.83 \pm 0.35$ & $5.50 \pm 0.15^{\star *}$ & -29.76 \\
\hline Urea mg/dl & $24.42 \pm 0.81$ & $23.89 \pm 0.76$ & -2.13 & $23.79 \pm 0.82$ & $24.46 \pm 0.92$ & 2.82 \\
\hline Creatinine $(\mathrm{mg} / \mathrm{dl})$ & $0.91 \pm 0.023$ & $0.87 \pm 0.036$ & -4.40 & $0.94 \pm 0.024$ & $0.91 \pm 0.016$ & -3.19 \\
\hline Creatinine clearance & $109.67 \pm 5.32$ & $118.68 \pm 9.08$ & 8.22 & $102.36 \pm 3.53$ & $103.37 \pm 4.91$ & 0.98 \\
\hline Uromodulin (ng/ml) & $2.57 \pm 0.092$ & $2.97 \pm 0.19^{*}$ & 15.56 & $2.99 \pm 0.31$ & $3.27 \pm 0.34^{* *}$ & 9.37 \\
\hline Creatinine/uromodulin ratio & $0.375 \pm 0.02$ & $0.339 \pm 0.33$ & -9.60 & $0.371 \pm 0.017$ & $0.328 \pm 0.017^{*}$ & -11.59 \\
\hline
\end{tabular}

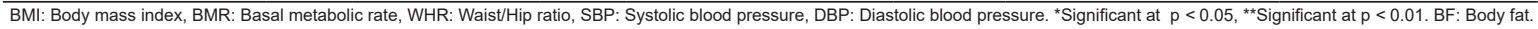

Table 6: Correlation coefficient of serum uromodulin and some anthropometric and biochemical parameters

\begin{tabular}{|c|c|c|c|c|c|}
\hline Parameters & $\begin{array}{l}\text { All cases } \\
\text { Before intervention }\end{array}$ & $\begin{array}{l}\text { Corn pie } \\
\text { Before intervention }\end{array}$ & $\begin{array}{l}\text { Barley Talbina } \\
\text { Before Intervention }\end{array}$ & $\begin{array}{l}\text { Corn pie } \\
\text { After intervention }\end{array}$ & $\begin{array}{l}\text { Barley Talbina } \\
\text { After Intervention }\end{array}$ \\
\hline \multicolumn{6}{|l|}{$\mathrm{BF} \%$} \\
\hline Pearson correlation & 0.010 & 0.055 & -0.046 & -0.002 & -0.197 \\
\hline Sig. (2-tailed) & 0.934 & 0.759 & 0.790 & 0.990 & 0.250 \\
\hline No. & 70 & 34 & 36 & 34 & 36 \\
\hline \multicolumn{6}{|l|}{ WHR } \\
\hline Pearson correlation & -0.005 & $-0.339^{*}$ & 0.066 & -0.138 & 0.098 \\
\hline Sig. (2-tailed) & 0.968 & 0.050 & 0.700 & 0.438 & 0.571 \\
\hline No. & 70 & 34 & 36 & 34 & 36 \\
\hline \multicolumn{6}{|l|}{ Neck circumference } \\
\hline Pearson correlation & $-0.264^{*}$ & 0.078 & -0.323 & 0.017 & -0.308 \\
\hline Sig. (2-tailed) & 0.027 & 0.660 & 0.055 & 0.925 & 0.068 \\
\hline No. & 70 & 34 & 36 & 34 & 36 \\
\hline \multicolumn{6}{|l|}{ Non-HDL-C } \\
\hline Pearson correlation & -0.090 & -0.165 & -0.159 & -0.162 & 0.052 \\
\hline Sig. (2-tailed) & 0.458 & 0.352 & 0.353 & 0.360 & 0.762 \\
\hline No. & 70 & 34 & 36 & 34 & 36 \\
\hline \multicolumn{6}{|l|}{ Risk factor } \\
\hline Pearson correlation & -0.198 & $-0.363^{*}$ & -0.246 & $-0.345^{*}$ & -0.126 \\
\hline Sig. (2-tailed) & 0.101 & 0.035 & 0.149 & 0.046 & 0.464 \\
\hline No. & 70 & 34 & 36 & 34 & 36 \\
\hline \multicolumn{6}{|l|}{ SBP } \\
\hline Pearson correlation & 0.007 & -0.330 & 0.116 & -0.304 & $0.346^{*}$ \\
\hline Sig. (2-tailed) & 0.951 & 0.057 & 0.501 & 0.080 & 0.039 \\
\hline No. & 70 & 34 & 36 & 34 & 36 \\
\hline \multicolumn{6}{|l|}{ DBP } \\
\hline Pearson correlation & -0.053 & -0.290 & 0.012 & -0.280 & $0.552^{\star \star}$ \\
\hline Sig. (2-tailed) & 0.661 & 0.096 & 0.946 & 0.109 & 0.000 \\
\hline No. & 70 & 34 & 36 & 34 & 36 \\
\hline \multicolumn{6}{|l|}{ Creatinine } \\
\hline Pearson correlation & 0.057 & $0.409^{*}$ & -0.094 & 0.262 & $0.452^{\star *}$ \\
\hline Sig. (2-tailed) & 0.636 & 0.016 & 0.587 & 0.134 & 0.006 \\
\hline No. & 70 & 34 & 36 & 34 & 36 \\
\hline \multicolumn{6}{|l|}{ Urea } \\
\hline Pearson correlation & $0.374^{\star \star}$ & -0.191 & $0.599^{* *}$ & -0.058 & $0.334^{*}$ \\
\hline Sig. (2-tailed) & 0.001 & 0.278 & 0.000 & 0.743 & 0.046 \\
\hline No & 70 & 34 & 36 & 34 & 36 \\
\hline \multicolumn{6}{|l|}{ Creatinine/sUMOD } \\
\hline Pearson correlation & $-0.713^{\star *}$ & $-0.843^{* *}$ & $-0.668^{\star *}$ & $-0.862^{\star \star}$ & $-0.745^{\star *}$ \\
\hline Sig. (2-tailed) & 0.000 & 0.000 & 0.000 & 0.000 & 0.000 \\
\hline No & 70 & 34 & 34 & 36 & 36 \\
\hline
\end{tabular}


Before intervention the whole sample showed negative significant correlation with neck circumference (NC) $(p \leq 0.05)$ and creatinine/sUMOD ratio $(p \leq 0.01)$, and negative non-significant correlation with WHR, nonHDL-C, risk factor, and DBP. Furthermore, before intervention corn pie group showed negative significant correlation with WHR, risk factor, and creatinine/sUMOD ratio, while Barley Talbina group showed negative significant correlation only with creatinine/sUMOD. After intervention corn pie group revealed negative non-significant correlation with the most investigated parameters; however, significant level ( $p \leq 0.01$ ) was found with the risk factors and creatinine/sUMOD ratio, while for Barley Talbina group the negative nonsignificant correlation was detected with NC, body fat percent, risk factor, and negative significant correlation only with creatinine/sUMOD. Creatinine and urea mostly showed positive correlation.

Figures 1 and 2 show the relative area (\%) of fatty acids in the corn pie and Barely Talbina. The results showed that the nutritional supplement Talbina contains a greater percentage of omega-fatty acids than the corn pie. Their contents from the omega fatty acids linoleic and linolenic were $13.90,27.90 \%$ for corn pie and $37.39,39.70 \%$ for Talbina.

\section{Discussion}

sUMOD is a biomarker that has the advantage of anti-inflammatory and renal protection functions [31]. Until today, the physiological function of sUMOD is elusive, yet sUMOD arose as a profoundly intriguing marker of kidney function [32], [33]. As a tubular protein, sUMOD does not straight forwardly rely upon glomerular filtration, yet reflects the tubular integrity and by implication the nephron mass and accordingly the renal reserve [34].

D'Agati et al. reported that obesity was considered as one important risk factor for CKD [35]. The pandemic of obesity has fueled an expanded prevalence of obesity-related glomerulopathy (ORG), and the unmistakable cause of CKD characterized by sub-nephrotic proteinuria, glomerulomegaly, and

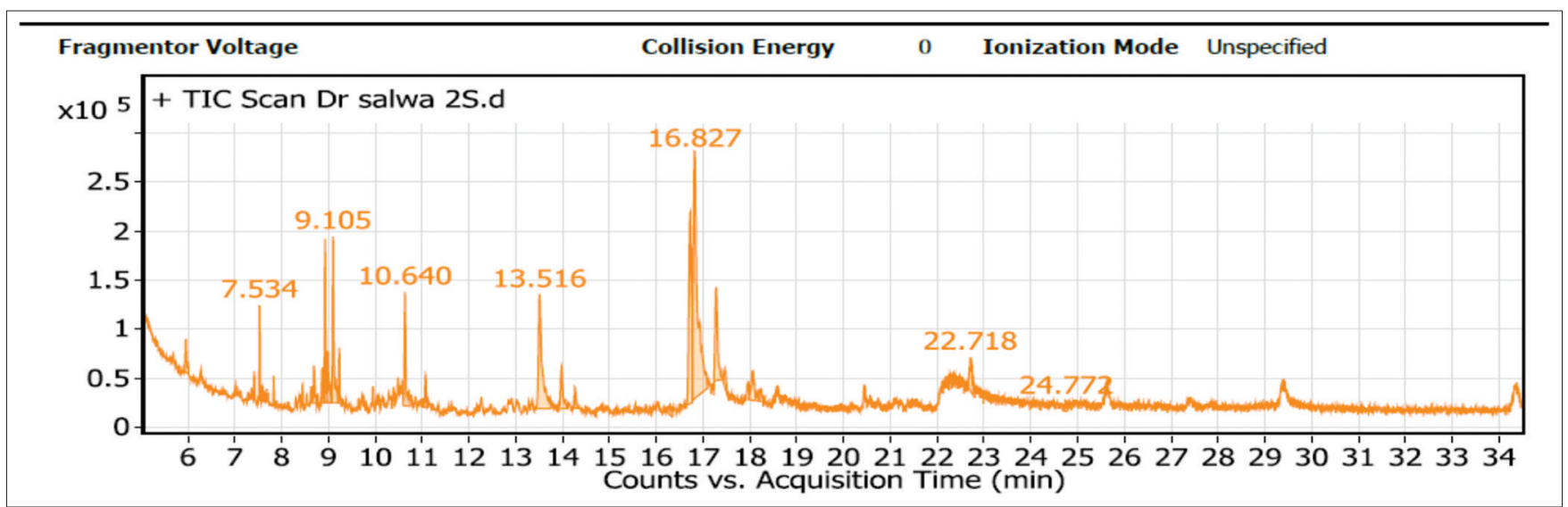

Figure 1: Relative area (\%) of fatty acids in corn pie, at RT (13.522 min) palmitic acid (C16:0 min), 11.22\%, at RT (16.736 min) linoleic acid (C18:2, n-6), $13.9 \%$, and at RT (16.827 min) linolenic acid (C18:3, $n-3), 27.9 \%$

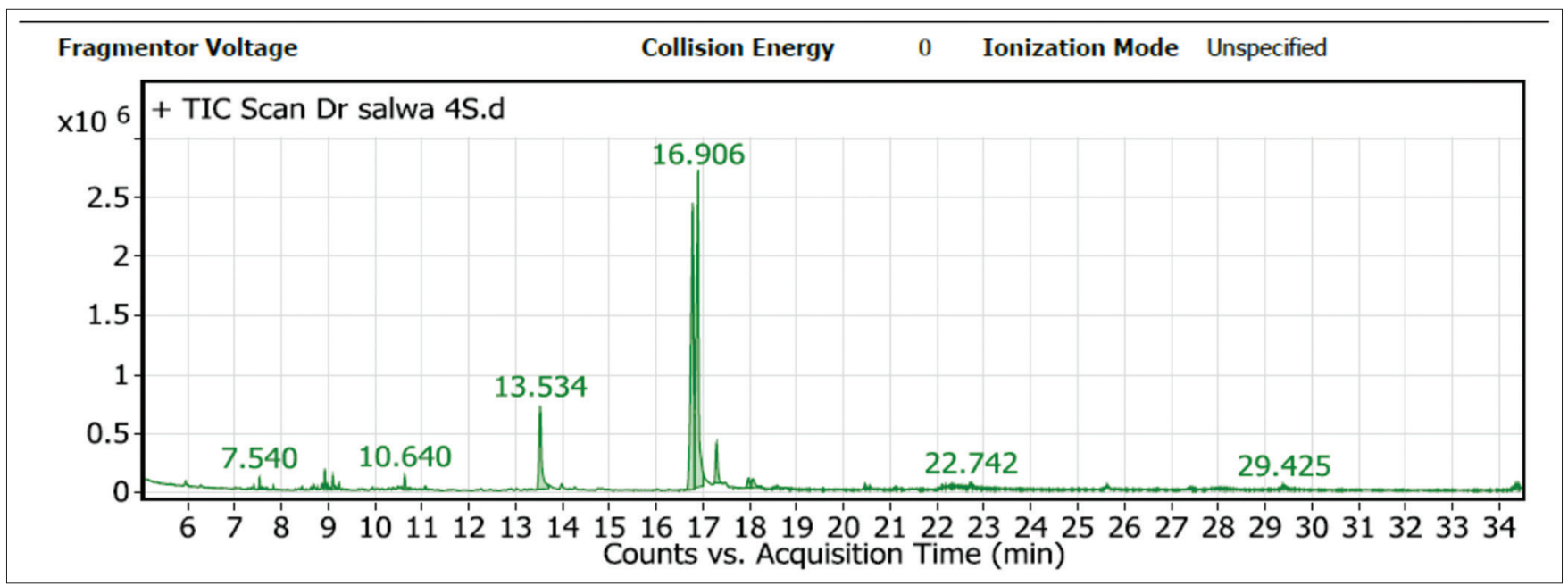

Figure 2: Relative area (\%) of fatty acids in Barley Talbina blend, at RT (13.534 min) palmitic acid (C16:0), 10.85\%, at RT (16.791 min) linoleic acid (C18:2, n-6), 37.39\%, and at RT (16.906 min) linolenic acid (C18:3, n-3), 39.7\% 
progressive loss of the renal functions. Obesity cause glomerular hyperfiltration that causes afferent arteriolar ultrafiltration [36]; as a result, more over numerous patients with ORG create an adaptive frame of focal segmental glomerulosclerosis [37].

In this study, data reported by dietary history revealed that the diet consumed by the participants after they have followed the described dietary regimen which composed of low caloric diet plus the two supplements containing bioactive ingredients, resulted in decrease the daily total calorie intake. While the percentage of the calories derived from their protein, MUSFAs and PUSFAs intake increased, but were within the recommended daily allowance. Associated with this dietary therapy, significant decreases of the anthropometric measurements of the obese participants were reported. Furthermore, an improvement in the metabolic profile was found among participants after intervention as was evident from the improvement of the average calculated risk factor. This improvement might be caused by the fact that both supplements are rich in omega 3 fatty acids. On the other hand, data also showed significant increase in the mean of the SUMOD concentration after the intervention along with loosing body weight which indicating that obesity and the associated metabolic abnormality may impair tubular integrity and protein synthesis. However, creatinine and urea levels that related to filtration capacity of the kidney showed minor improvement. In this text, the mean value of the creatinine/uromodulin ratio decreased after intervention in both groups and reached significant difference for participants who consumed Barley Talbina supplement, Then et al. [12] said that metabolic factors may negatively influence sUMOD levels, indicating that the metabolic syndrome may impair tubular integrity and protein synthesis. Recently, Scheurlen et al. described an increment of sUMOD concentration in patients with extreme obesity after Roux-en-Y-gastric bypass, demonstrating improved "kidney functions" or renal reserve after bariatric surgery, which was not distinguishable by conventional kidney function markers [38]. Developing evidence proposes oxidative stress plays a part as the basic cause connecting obesity with its related complications [39], in this setting LaFavers et al. reported that sUMOD represses the era of reactive oxygen species both systemically and within the kidney [40].

The chemical analysis showed that each of the two supplements contains a balanced amount of mineral salts, which gives it an advantage in maintaining the healthy kidney functions. Farhadnejad et al. found that magnesium and potassium were associated with a decreased risk, while sodium was associated with an increased risk of incident CKD [41].

In this study, low sUMOD levels in the whole sample were negatively associated with a single measurement from among the other anthropometric measurements that were used to assess obesity, namely the NC. After intervention both groups showed increase in the concentration of the SUMOD, but only the group consumed Barley Talbina still kept this negative correlation. Framingham heart study illustrated that NC was independently related with visceral obesity and BMI. NC plays an independent commitment to predict the metabolic complications beyond the norm classical anthropometric parameters of BMI, waist circumference, and WHR and may be utilized as an ideal screening for obesity related chronic diseases [42], [43]. Our results confirmed the importance of NC measurement, as we did not find any association between SUMOD and the other parameters in the whole sample. However, group (1) showed significant negative correlation with WHR before intervention.

Several genome-wide association studies have found common variants within the promoter region of the UMOD gene which considered risk factors for progression to CKD and hypertension [44], [45], [46], and therefore, the sUMOD levels correlate with mortality in patients with cardiovascular disorder [47], [48]. Each of the established risk factors for cardiovascular disease - age, gender, diabetes mellitus, dyslipidemia, hypertension, and smoking - have been appropriately highlighted as useful for prediction of risk [49]. Data of this study revealed negative association of SUMOD with the risk factor (TC/HDL-C) which reached significant level in group (1) before and after intervention, this may be added to the previous evidence for the role of sUMOD in protection against cardiovascular disease. The high mean risk factor recorded among the participants especially before intervention may be due to the fact that they were suffering from obesity and dyslipidemia, as indicated by the high mean BMI and non-HDL-C levels.

Diet and nutrition are important factors within the promotion and maintenance of fine health throughout the complete life course. Their role as determinants of chronic non-communicable disease is well established and that they therefore occupy a prominent situation in prevention activities [50]. Since whole grains are complex mixtures of nutrients and phytochemicals, which can work together to stop chronic disease, no single nutrient, phytochemical, or specific combination has been identified as being answerable for their health benefits [51]. Data of this study showed that consuming whole grains help to lower body weight and BF. Giacco et al. reported that several mechanisms could also be involved, including satiety lower glycemic index, lower energy density of whole grain products, and modulating levels and kinds of bacteria within the intestinal tract [52]. The role of whole grains within the diet of patients having renal disease should be reconsidered. There are data suggesting that the bioavailability of phosphate from whole grains is low, despite their high phosphate content. This low bioavailability is said to be the cause of the shortage of the phytase, an enzyme required to release phosphorus from phytate, 
the most storage type of phosphate in whole grains. Considering whole grains for the kidney diet, the diet would be enriched and to supply the needed fiber in addition to its health benefits, diversify the diet with low sodium choices, and possibly supply adequate protein without increasing phosphorous levels [53]. Furthermore, there are increasing consumer demands for foods which contain ingredients that may impart health benefits beyond basic nutrition, including herbal. Among the herbs, thyme herb which employed in manufacture of corn pie has the very best antioxidant levels among herbs. It is packed with minerals and vitamins that are essential for optimum health [54]. The second food supplement Barley Talbina, which was used with the second group, contained cocoa powder and ginger; Yang et al. (2014) reported that cocoa is one of the richest sources of polyphenols and flavanols both have high antioxidant and anti-inflammatory effects [55]. Ginger mediated suppression of renal over-expression of pro-inflammatory cytokines. The important active component of ginger root is that the unpredictable oil and effective phenol compounds, as an example, gingerol, which may be a very powerful anti-inflammatory compound [56]. Gingerol has seemed to stabilize plasma lipid profile, adipocyte hormones, and lipases in high fat diet induced obese rats [57].

\section{Limitations}

This analysis was limited to the effect of the dietary regimen and the supplements and did not take into account for other lifestyle behaviors. In addition, future studies may need a longer test period and more participants.

\section{Conclusion}

The data of this study revealed the importance of using dietary therapy composed of hypocaloric diet in addition to supplements made of whole grains and special herbs in protecting and managing participants who suffer from obesity and its metabolic disorders from developing kidney diseases. At the same time, the results also showed the measurement of the SUMOD as a precise and accurate biochemical marker that showed the speed of the kidneys' response to management by comparison with using usual diagnostic old markers.

\section{Acknowledgments}

The authors would like to acknowledge the volunteer females for their participation in this study.
We also express our thanks to National Research Centre in Egypt, for project foundation. The project number "1205020"entitled "Metabolic Syndrome and the Development of CKDs; early diagnosis and better dietary tools for prevention and management."

\section{Authors' Contribution Statement}

Salwa M. El Shebini designed the study and wrote the article, Maha I. A. Moaty was responsible for clinical examination, anthropometrics measurements, weekly follow-up, and interpreted the data, Nihad $\mathrm{H}$. Ahmed was responsible for analysis of the nutritional intake and dietary habit and interpreted the data, Hend A. Essa was responsible for biochemical analysis and laboratory investigations and interpreted the data, Ahmed M. S. Hussein was responsible about preparing and manufacturing the supplements, Ahmed M. S. Hussein and Magda S. Mohamed were responsible for chemical analysis of the supplements, and Salwa T. Tapozada reviews the article. All authors read and approved the final manuscript.

\section{References}

1. Chen J, Gu D, Chen CS, Wu X, Hamm L, Muntner P, et al Association between the metabolic syndrome and chronic kidney disease in Chinese adults. Nephrol Dial Transplant. 2007;22(4):1100-6. https://doi.org/10.1093/ndt/gfl759 PMid: 17272313

2. Lea J, Cheek D, Thornley-Brown D, Appel L, Agodoa L, Contreras G, et al. Metabolic syndrome, proteinuria, and the risk of progressive CKD in hypertensive African Americans. Am J kidney Dis. 2008;51(5):732-40. https://doi.org/10.1053/j. ajkd.2008.01.013

PMid: 18436083

3. Nugent RA, Fathima SF, Feigl AB, Chyung D. The burden of chronic kidney disease on developing nations: A $21^{\text {st }}$ century challenge in global health. Nephron Clin Pract. 2011;118(3):c269-77. https://doi.org/10.1159/000321382 PMid:21212690

4. Laliberté F, Bookhart BK, Vekeman F, Corral M, Duh MS, Bailey RA, et al. Direct all-cause health care costs associated with chronic kidney disease in patients with diabetes and hypertension: A managed care perspective. J Manag Care Pharm. 2009;15(4):312-22. https://doi.org/10.18553/ jmcp.2009.15.4.312

PMid:19422271

5. Ohta M, Babazono T, Uchigata Y, Iwamoto Y. Comparison of the prevalence of chronic kidney disease in Japanese patients with Type 1 and Type 2 diabetes. Diabet Med. 2010;27(9):1017-23. https://doi.org/10.1111/j.1464-5491.2010.03049.x PMid:20722675

6. Altun B, Süleymanlar G, Utaş C, Arınsoy T, Ateş K, Ecder T, et al. Prevalence, awareness, treatment and control of hypertension 
in adults with chronic kidney disease in Turkey: Results from the CREDIT study. Kidney Blood Press Res. 2012;36(1):36-46. https://doi.org/10.1159/000339025

\section{PMid:22832670}

7. Hallan S, de Mutsert R, Carlsen S, Dekker FW, Aasarød K Holmen J. Obesity, smoking, and physical inactivity as risk factors for CKD: Are men more vulnerable? Am J Kidney Dis. 2006;47(3):396-405. https://doi.org/10.1053/j.ajkd.2005.11.027 PMid:16490617

8. EL-Nahass A, Bello AK. Chronic kidney disease: The global challenge. Lancet. 2005;95(9456):331-40.

PMid:15664230

9. Iseki K, Kohagura K, Sakima A, Iseki C, Kinjo K, Ikemiya Y, et al. Changes in the demographics and prevalence of chronic kidney disease in Okinawa, Japan (1993 to 2003). Hypertens Res. 2007;30(1):55-62. https://doi.org/10.1291/hypres.30.55 PMid: 17460372

10. Afifi A, Karim MA. Renal replacement therapy in Egypt: First annual report of the Egyptian society of Nephrology, 1996. East Mediterr Health J. 1999;5(5):1023-9. PMid:10983543

11. Afifi A, El Setouhy M, El Sharkawy M, Ali M, Ahmed $H$, El-Menshawy O, et al. Diabetic nephropathy as a cause of endstage renal disease in Egypt: A six-year study. East Mediterr Health J. 2004;10(4-5):620-6.

PMid: 16335654

12. Then $C$, Then $H$, Lechner $A$, Huth $C$, Meisinger $C$, Heier $M$, et al. Serum uromodulin is inversely associated with the metabolic syndrome in the KORA F4 study. Endocr Connect. 2019;8(10):1363-71. https://doi.org/10.1530/ec-19-0352 PMid:31505464

13. Brunati M, Rampoldi L. Kidney diseases associated with uromodulin (Tamm-Horsfall protein. G Ital Nefrol. 2015;32 Suppl 64:gin/32.S64.10. PMid:26479057

14. Rees K, Takeda A, Martin N, Ellis L, Wijesekara D, Vepa A, et al. Mediterranean-style diet for the primary and secondary prevention of cardiovascular disease. Cochrane Database Syst Rev. 2019;3(3):CD009825. https://doi.org/10.1002/14651858. cd009825.pub3 PMid:30864165

15. Rees K, Hartley L, Flowers N, Clarke A, Hooper L, Thorogood M, et al. 'Mediterranean' dietary pattern for the primary prevention of cardiovascular disease. Cochrane Database Syst Rev. 2013;8:CD009825. https://doi.org/10.1002/14651858. cd009825.pub2 PMid:23939686

16. Lankinen M., Uusitupa M., Schwab U. Nordic diet and inflammation-a review of observational and intervention studies. Nutrients. 2019;11(6):1369. https://doi.org/10.3390/nu11061369 PMid:31216678

17. Messias Rda S, Galli V, Silva SD, Schirmer MA, Rombaldi CV. Micronutrient and functional compounds biofortification of maize grains. Crit Rev Food Sci Nutr. 2015;55(1):123-39. https://doi. org/10.1080/10408398.2011.649314 PMid:24915397

18. Zeng Y, Pu X, Yang J, Du J, Yang X, Li X, et al. Preventive and therapeutic role of functional ingredients of barley grass for chronic diseases in human beings. Oxid Med Cell Longev. 2018;2018:3232080. https://doi.org/10.1155/2018/3232080 PMid:29849880

19. Guiné RP, Gonçalves FJ. Bioactive compounds in some culinary aromatic herbs and their effects on human health. Mini Rev Med Chem. 2016;16(11):855-66. https://doi.org/10.2174/138955751
6666160211120540

PMid:26864553

20. AOAC. 2000 Official Methods of Analysis of AOAC International. $17^{\text {th }}$ ed. Maryland, USA: North Frederick Avenue Gaithersburg; 2000. p. 2877-417.

21. Kazuyoshi T, Yuuko I. Comparison of digestion methods for atomic absorption analysis of food materials. Anal Sci. 1992;8:419-21

22. Mazurek B, Chmiel M, Górecka B. Food Analytical Methods. Berlin: Springer; 2017

23. Cheung LM, Cheung PC, Ooi VE. Antioxidant activity and total phenolics of edible mushroom extracts. Food Chem. 2003;81:24955. https://doi.org/10.1016/s0308-8146(02)00419-3

24. Hiernaux J, Tanner JM. Growth and Physical Studies in Humanbiology: A Guide to Field Methods No. 23, World Food Dietary Assessment System; 1969.

25. Allain CC, Poon LS, Chan CS, Richmond WF, Fu PC Enzymatic determination of total serum cholesterol. Clin Chem. 1974;20(4):470-5. https://doi.org/10.1093/clinchem/20.4.470 PMid:4818200

26. Wornick DF, Albers JJ. A comprehensive evaluation of the heparin-manganese precipitation procedure for estimating high density lipoprotein cholesterol. J Lipid Res. 1978;19(1):65-76. https://doi.org/10.1016/s0022-2275(20)41577-9 PMid:202660

27. Lhotta K. Uromodulin and chronic kidney disease Kidney Blood Press Res. 2010;33(5):393-8. https://doi. org/10.1159/000320681

PMid:20948228

28. Cockcroft DW, Gault MH. Prediction of creatinine clearance from serum creatinine. Nephron. 1976;16(1):31-41. https://doi. org/10.1159/000180580

PMid:1244564

29. Fawcett JK, Scott JE. A rapid and precise method for the determination of urea. J Clin Pathol. 1960;13(2):156-9.

PMid:13821779

30. Risch L, Lhotta K, Meier D, Medina-Escobar P, Nydegger UE, Risch $\mathrm{M}$. The serum uromodulin level is associated with kidney function. Clin Chem Lab Med. 2014;52(12):1755-61. https://doi. org/10.1515/cclm-2014-0505

PMid:24933630

31. Bjornstad P, Wiromrat $P$, Johnson RJ, Sippl R, Cherney DZ, Wong $\mathrm{R}$, et al. Serum uromodulin predicts less coronary artery calcification and diabetic kidney disease over 12 years in adults with Type 1 diabetes: The CACTI study. Diabetes Care. 2019;42(2):297-302. https://doi.org/10.2337/dc18-1527 PMid:30482755

32. Steubl D, Block M, Herbst $V$, Nockher WA, Satanovskij $R$, Angermann $\mathrm{S}$, et al. Plasma uromodulin correlates with kidney function and identifies early stages in chronic kidney disease patients. Medicine (Baltimore). 2016;95(10):e3011. https://doi. org/10.1097/md.0000000000003011 PMid:26962815

33. Scherberich JE, Gruber R, Nockher WA, Christensen EI, Schmitt $H$, Herbst $V$, et al. Serum uromodulin-a marker of kidney function and renal parenchymal integrity. Nephrol Dial Transplant. 2018;33(2):284-95. https://doi.org/10.1093/ndt/ gfw422

PMid:28206617

34. Pivin E, Ponte B, de Seigneux S, Ackermann D, Guessous I, Ehret $\mathrm{G}$, et al. Uromodulin and nephron mass. Clin J Am Soc Nephrol. 2018;12(10):1556-7. https://doi.org/10.2215/ cjn.03600318

PMid:30054352 
35. D'Agati VD, Chagnac A, de Vries AP, Levi M, Porrini E, HermanEdelstein M, et al. Obesity-related glomerulopathy: Clinical and pathologic characteristics and pathogenesis. Nat Rev Nephrol. 2016;12(8):453-71. https://doi.org/10.1038/nrneph.2016.75 PMid:27263398

36. Chagnac A, .Weinstein T, Korzets A, Ramadan E, Hirsch J, Gafter U. Glomerular hemodynamics in severe obesity. Am J Physiol Renal Physiol. 2000;278(5):F817-22. https://doi. org/10.1152/ajprenal.2000.278.5.f817 PMid:10807594

37. Rosenberg AZ, Kopp JB. Focal segmental glomerulosclerosis. Clin J Am Soc Nephrol. 2017;12(3):502-17. PMid:28242845

38. Scheurlen KM, Billeter AT, Kopf $S$, Herbst V, Block $M$, Nawroth PP, et al. Serum uromodulin and Roux-en-Y gastric bypass: Improvement of a marker reflecting nephron mass. Surg Obes Relat Dis. 2019;15(8):1319-25. https://doi.org/10.1016/j. soard.2019.05.002 PMid:31239098

39. Manna P, Jain SK. Obesity, oxidative stress, adipose tissue dysfunction, and the associated health risks: Causes and therapeutic strategies. Metab Syndr Relat Disord. 2015;13(10):423-44. https://doi.org/10.1089/met.2015.0095 PMid:26569333

40. LaFavers KA, Macedo E, Garimella PS, Lima C, Khan S, Myslinski J, et al. Circulating uromodulin inhibits systemic oxidative stress by inactivating the TRPM2 channel. Sci Transl Med. 2019;11(512):eaaw3639. https://doi.org/10.1126/ scitransImed.aaw3639

PMid:31578243

41. Farhadnejad H, Asghan G, Mirmiran P, Yuzbashian E, Azizi F. Micronutrient intakes and incidence of chronic kidney disease in adults: Tehran lipid and glucose study. Nutrients. 2016;8(4):217. https://doi.org/10.3390/nu8040217

PMid:27104561

42. Zhou JY, Ge H, Zhu MF, Wang LJ, Chen L, Tan YZ, et al. Neck circumference as an independent predictive contributor to cardio-metabolic syndrome. Cardiovasc Diabetol. 2013;12:76. https://doi.org/10.1186/1475-2840-12-76 PMid:23680280

43. Preis SR, Massaro JM, Hoffmann U, D'Agostino RB Sr., Levy D, Robins SJ, et al. Neck circumference as a novel measure of cardiometabolic risk: The Framingham heart study. J Clin Endocrinol Metab. 2010;95(8):3701-10. https://doi.org/10.1210/ jc.2009-1779

PMid:20484490

44. Köttgen A, Glazer NL, Dehghan A, Hwang SJ, Katz R, Li M, et al. Multiple loci associated with indices of renal function and chronic kidney disease. Nat Genet. 2009;41(6):712-7. PMid:19430482

45. Köttgen A, Hwang SJ, Larson MG, van Eyk JE, Fu Q, Benjamin EJ, et al. Uromodulin levels associate with a common UMOD variant and risk for incident CKD. J Am Soc Nephrol.
2010;21(2):337-44. https://doi.org/10.1681/asn.2009070725 PMid: 19959715

46. Trudu M, Janas S, Lanzani C, Debaix H, Schaeffer C, Ikehata M, et al. Common noncoding UMOD gene variants induce saltsensitive hypertension and kidney damage by increasing uromodulin expression. Nat Med. 2013;19:1655-60. https://doi. org/10.1038/nm.3384

PMid:24185693

47. Leiherer A, Muendlein A, Saely $\mathrm{CH}$, Ebner J, Brandtner EM, Fraunberger $\mathrm{P}$, et al. Serum uromodulin is a predictive biomarker for cardiovascular events and overall mortality in coronary patients. Int J Cardiol. 2017;231:6-12. https://doi.org/10.1016/j. ijcard.2016.12.183

PMid:28089453

48. Delgado GE, Kleber ME, Scharnagl H, Krämer BK, März W, Scherberich JE. Serum uromodulin and mortality risk in patients undergoing coronary angiography. J Am Soc Nephrol. 2017;28(7):2201-10. https://doi.org/10.1681/asn.2016111162 PMid:28242751

49. Wilson PW, D'Agostino RB, Levy D, Belanger AM, Silbershatz H, Kannel WB. Prediction of coronary heart disease using risk factor categories. Circulation. 1998;97(18):1837-47. https://doi. org/10.1161/01.cir.97.18.1837 PMid:9603539

50. World Health Organization. The World Health Report 2002: Reducing Risks, Promoting Healthy Life. Geneva: World Health Organization; 2002. https://doi.org/10.1016/j. agecon.2003.11.006

51. Webb $D$. The impact of whole grains on health. Todays Dietitian. 2013;15(5):44.

52. Giacco R, Pepa GD, Luongo D, Riccardi G. Whole grain intake in relation to body weight: From epidemiological evidence to clinical trials. Nutr Metab Cardiovasc Dis. 2011;21(12):901-8. https://doi.org/10.1016/j.numecd.2011.07.003 PMid:22036468

53. Williams C, Ronco C, Kotanko P. Whole grains in the renal diet-is it time to reevaluate their role? Blood Purif. 2013;36(34):210-4.https://doi.org/10.1159/000356683 PMid:24496192

54. Sharangi $A B$, Guha $S$. Wonders of leafy spices: Medicinal properties ensuring human health. Sci Int. 2013;1(9):312-7. https://doi.org/10.17311/sciintl.2013.312.317

55. Yang M, Liu C, Jiang J, Zuo G, Lin X, Yamahara J, et al. Ginger extract diminishes chronic fructose consumption-induced kidney injury through suppression of renal overexpression of proinflammatory cytokines in rats. BMC Complement Altern Med. 2014;14:174. https://doi.org/10.1186/1472-6882-14-174

56. Latona DF, Oyeleke GO, Olayiwola OA. Chemical analysis of ginger root. IOSR J Appl Chem 2012;1:47-9.

57. Boissonneault GA, Clinical and Scientific Affairs Council of the AAPA. Obesity: The current treatment protocols. JAAPA. 2009;22(1):18-9.

PMid:19248355 